\title{
PENGARUH BEBAN KERJA TERHADAP KINERJA PEGAWAI PADA BADAN PENGELOLAAN LINGKUNGAN HIDUP DAERAH PROVINSI LAMPUNG
}

\author{
Melia Santi ${ }^{(1)}$, Trisnowati Josiah ${ }^{(2)}$, Fahrizi $^{(3)}$ \\ Fakultas Ekonomi Universitas Sang Bumi Ruwa Jurai \\ meliaasanti10@gmail.com,trisnowati.josiah@fe.saburai.ac.id,fahrizi@fe.saburai.ac.id
}

\begin{abstract}
Abstrak. Pegawai Negeri Sipil (PNS) adalah penting dan menentukan karena merupakan unsur aparatur Negara untuk menyelenggarakan pemerintah dan pembangunan dalam rangka usaha mencapai tujuan pembangunan nasional. Terdapat beberapa faktor penyebab beban kerja pada Pegawai Negeri Sipil adalah kecemburuan sosial karena karier melesat naik, menerima tugas yang terlalu banyak dan bertubi-tubi, serta kurangnya dukungan dari atasan. Objek penelitian adalah Kantor Badan Pengelolaan Lingkungan Hidup Daerah Provinsi Lampung yang beara di Jl. Basuki Rachmat No. 10 Teluk Betung Selatan Kota Bandar Lampung. Tujuan dari penelitian ini adalah Untuk mengetahui pengaruh beban kerja terhadap kinerja pegawai BPLHD Provinsi Lampung.Pengujian data menggunakan metode analisis kualitatif dan analisis kuantitaif. Hasil pengujian hipotesis menunjukan bahwa tingkat kepercayaan 95\% dan derajat kebebasan sebesar 32, nilai t hitung 4,864 adalah lebih besar dari t tabel 1,691. Hal ini berarti bahwa beban kerja memiliki pengaruh yang signifikan terhadap kinerja pegawai BPLHD Provinsi Lampung.
\end{abstract}

Kata kunci: Pegawai,Kinerja, Beban Kerja, SDM.

\section{PENDAHULUAN}

Peranan dan kedudukan Pegawai Negeri Sipil (PNS) adalah penting dan menentukan karena merupakan unsur aparatur Negara untuk menyelenggarakan pemerintah dan pembangunan dalam rangka usaha mencapai tujuan pembangunan nasional. Telah kita ketahui Pegawai Negeri Sipil (PNS) di indonesia sangat penting untuk menentukan untuk masa depan pembangunan bangsa. Hal ini dikarenakan merupakan salah satu aparatur Negara yang membangun tugas dan tanggung jawab yang cukup berat atas segala pengabdiannya pada Negara. Ditegaskan dalam Undang-undang Nomor 8 Tahun 1974 tentang Pokok-pokok Kepegawaian. Terlihat jelas dalam Undangundang tersebut, bahwa sebagai aparatur Negara dalam suatu instasi pemerintah, pegawai negeri merupakan unsur yang sangat penting yang harus dipelihara dan dibina agar dapat tercapainya keberhasilan dalam pencapaian pembangunan, untuk mensejahterahkan masyarakat dan mewujudkan kelancaran, keterpaduan tugas dan fungsi penyelenggaraan Pemerintah Negara serta dapat menghasilkan sumber daya manusia yang handal, professional, efektif, efesien dan tanggap dengan kondisi masyarakat dalam dinamika pembangunan.

Faktor-faktor penyebab beban kerja adalah kecemburuan sosial karena karier melesat naik, menerima tugas yang terlalu banyak dan bertubi-tubi, serta kurangnya dukungan dari atasan. Beban kerja memicu pengaruh negatif sehingga dapat mempengaruhi kualitas pekerjaan yang dilakukan para pegawai. Beban kerja juga berkelanjutan dapat menurunkan konsentrasi mereka dalam mengatasi masalah dan menurunkan rasa tanggung jawab untuk melakukan pekerjaan, bekerja 
kurang profesional, dan motivasi kerja menurun.

Badan Pengelolaan Lingkungan Hidup Daerah Provinsi Lampung (BPLHD) merupakan unsur pendukung tugas Kepala Badan yang melaksanakan urusan pemerintah daerah yang dipimpin oleh seorang Kepala Badan yang bertanggung jawab kepada Gubernur melalui Sekretaris Daerah.

BPLHD mempunyai tugas dan fungsi sebagai berikut :

a. Perumusan kebijakan teknis pengelolaan lingkungan.

b. Pemberian dukungan atas penyelenggaraan pemerintah daerah dibidang pengelolaan lingkungan hidup.

c. Pelaksanaan tugas lain yang diberikan oleh Gubernur dibidang pengelolaan lingkungan hidup.

Cara perhitungan singkat absensi pegawai BPLHD Provinsi Lampung adalah dengan menghitung jumlah absensi dalam ukuran hari atau dengan menjumlahkan hari ketidakhadiran seluruh pegawai selanjutnya dibandingkan dengan total hari kerja pegawai. Umumnya ketidakhadiran pegawai disebabkan antara lain karena sakit, ada keperluan ataupun tanpa keterangan yang jelas.

Perhitungan tingkat absensi dengan rumus :

$$
\text { jumlah absensi }=\frac{\text { absensi }}{\text { harikerja }} \times 100 \%
$$

Semakin meningkat beban kerja maka kinerja semakin menurun. Beban kerja mengakibatkan sumber kesadaran atau pengertian individu berkurang. Keadaan ini berpengaruh kuat pada kemampuan pegawai dalam bekerja secara efisien dan efektif. Kinerja pada dasarnya adalah apa yang dilakukan atau tidak dilakukan pegawai. Kinerja pegawai adalah yang mempengaruhi seberapa banyak mereka memberi kontribusi kepada organisasi. Perbaikan kinerja baik untuk individu maupun kelompok menjadi pusat perhatian dalam upaya meningkatkan kinerja organisasi. Pengertian kinerja pegawai menunjuk pada kemampuan pegawai dalam melaksanakan keseluruhan tugas-tugas yang menjadi tanggung jawabnya. Tugastugas tersebut biasanya berdarkan indikator-indikator keberhasilan yang sudah diterapkan. Berdasarkan uraian-uraian tersebut, penulis mengambil judul "Pengaruh Beban Kerja Terhadap Kinerja Pegawai pada Badan Pengelolaan Lingkungan Hidup Daerah Provinsi Lampung”.

\section{KAJIAN TEORI}

\section{Pengertian Manajemen Sumber Daya Manusia}

Manajemen telah banyak disebut sebagai seni untuk menyelesaikan pekerjaan melalui orang lain. Definisi ini berarti bahwa pemimpin mencapai tujuantujuan organisasi melalui pengaturan orang lain untuk melaksanakan berbagai pekerjaan yang diperlukan. Pengertian manajemen sumber daya manusia dikemukaan oleh beberapa ahli yang mengartikannya berbeda-beda, tetapi pada prinsipnya memili arti yang sama.

Menurut Edwin B. Flippo (2008 : 15) manajemen sumber daya manusia adalah : Perencanaan, pengorganisasian, dan pengawasan kegiatan-kegiatan pengadaan, pengembangan pemberian kompensasi, pengintegrasian, pemeliharaan dan pelepasan sumber daya manusia agar tercapai tujuan individu, organisasi, dan masyarakat.

Sedangkan menurut Wendell French dalam T. Hani Handoko (2006 : 23) manajemen sumber daya manusia adalah : Penarikan, seleksi, pengembangan, penggunaan dan pemeliharaan sumber daya manusia oleh organisasi. 
Berdasarkan kedua definisi tersebut, dapat dikatakan bahwa manajemen sumber daya manusia adalah penarikan, seleksi, pengembangan, pemeliharaan, dan penggunaan sumber daya manusia untuk mencapai tujuan-tujuan individu maupun organisasi. Definisi ini menekankan kenyataan pengelolaan yang dilakukan adalah manusia terhadap manusia dan bukan terhadap material maupun finansial.

Bidang sumber daya manusia mempunyai dua fungsi pokok, dimana fungsi pertama berkaitan dengan fungsi kedua, yaitu :

1. Untuk menjalin kerjasama dalam pengembangan dan administrasi berbagai kebijaksanaan yang mempengaruhi orang-orang yang membentuk organisasi.

2. Untuk membantu pada manajer dalam mengelola sumber daya manusia.

3. Manajemen personalia menitikberatkan perhatian pada pengelolaan tenaga kerja sedimikian rupa agar tercapainya tujuan organisasi melalui kegiatan :

4. Memilih dan menempatkan orang yang tepat pada pekerjaan yang tepat.

5. Menggunakan tenaga kerja secara efektif dan efisien.

6. Mengembangkan tenaga kerja serta memelihatra hubungan kerjasama yang harmonis.

\section{Faktor - Faktor Penyebab Beban Kerja}

Terhadap beberapa faktor yang dapat mendorong pegawai mengalami beban pekerjaan. Diantaranya adalah ketidakjelasan apa yang menjadi tanggung jawab pekerjaan, kekurangan waktu untuk menyelesaikan tugas, tidak ada dukungan fasilitas untuk menjalankan pekerjaan, dan tugas-tugas pekerjaan yang saling bertentangan. Sementara dalam topik riset mengenai beban kerja, ada dua macam sumber beban kerja yang diteliti, yaitu ketidakjelasan peran (role ambiguity), konflik pekerjaan, beban pekerjaan (workload), dan ketidaksesuaian sumber daya atau fasilitas (resorce inadequacy), dan bahaya kerja yang dirasakan oleh pegawai (Istijanto dalam Suroso P. 2008 : 22) :

a. Faktor Ambiguitas Peran, Pegawai perlu mengetahui tujuan dari pekerjaan, apa yang diharapkan untuk dikerjakan dan tanggung jawab dari pekerjaan mereka agar menghasilkan performan yang baik. Saat tidak ada kepastian tentang definisi kerja dan apa yang diharapkan dari pekerjaannya akan timbul ambiguitas peran.

b. Konflik Pekerjaan, Konflik pekerjaan timbul jika seseorang pegawai mengalami adanya pertentangan tugastugas yang harus ia lakukan dan antara tanggung jawab yang ia miliki, tugastugas yang harus ia lakukan yang menurut pandangannya bukan merupakan bagian dari pekerjaannya, kemudian tuntutan-tuntutan yang bertentangan dari atasan, rekan, bawahannya, aau orang lain yang dinilai penting bagi dirinya, pertentangan dengan nilai-nilai dan keyakinan pribadinya sewaktu melakukan tugas pekerjaannya.

c. Beban Pekerjaan Yang Tinggi, Beban kerja yang tinggi merupakan salah satu penyebab kinerja sesorang menurun. Beban kerja berlebih timbul akibat dari tugas yang terlalu banyak kepada pegawai untuk diselaikan, serta tidak cukupnya waktu untuk menyelesaikan tugas.

d. Ketidak sesuaian Sumber Daya Atau Fasilitas, Hal ini merupakan salah satu faktor yang akan menetukan dapat terselesaikannya pekerjaan dengan baik atau tidak. Tidak memaidainya sarana dan prasara atau fasilitas kantor untuk melaksakan pekerjaan akan membuat pegawai kesulitan memenuhi kualitas pekerjaan yang dituntut organisasi. 
e. Bahaya Kerja Yang Dirasakan Oleh Pegawai, Bahaya kerja ini berhubungan dengan resiko pegawai dalam melaksanakan tugas yang akan mengancam keselamatan jiwa pegawai itu sendiri. Namun bagi pegawai BPLHD yang akan menjalankan tugas dikantor, maka bahaya kerja akan sangat minim terjadi, kecuali pada saat menjalankan tugas luar (tugas lapangan).

\section{Kinerja}

Pengertian kenerja adalah hasil kerja secara kualitas dan kuantitas yang dicapai oleh seorang pegawai dalam melaksanakan tugasnya sesuai tanggung jawab yang diberikan kepadanya.

Definisi kinerja menurut Hasibuan (2008 : 34) kinerja adalah suatu hasil kerja yang dicapai seseorang dalam melaksanakan tugas-tugas yang dibebankan kepadanya yang didasarkan atas kecakapan, pengalaman, dan kesungguhan.

Banyak yang bisa kita lihat pada kemampuan pegawai, seperti bahwa sesorang pegawai akan merasa termotivasi dan memiliki kinerja yang baik, jika seorang pegawai memiliki pengetahuan yang memadai terhadap bidang tugas dan tanggung jawabnya, kondisi fisik, adanya dukungan faktor keluarga serta tidak adanya hambatan. Menyediakan kesempatan bagi pegawai untuk meningkatkan pendidikan member jalan baji pegawai secara individual. Selain itu, bahwa pegawai dapat memiliki kemampuan yang baik jika ada faktor dukungan keluarga dan tidak ada hambatan dalam faktor geografis. Dua hal ini hampir sering luput dari perhatian pimpinan yang pengaruhnya sangatlah besar bagi kinerja para pegawai.

\section{METODE PENELITIAN}

\section{Objek Penelitian}

Dalam penelitian ini objek penelitian adalah Kantor Badan Pengelolaan Lingkungan Hidup Daerah Provinsi Lampung yang beara di Jl. Basuki Rachmat No. 10 Teluk Betung Selatan Kota Bandar Lampung. Penelitian dilaksanakan dari bulan Januari sampai Maret 2017.

\section{Metode dan Teknik Pengumpulan Data}

Dalam penelitian ini jenis data yang diperlakukan adalah :

\section{a. Data Primer}

Pengumpulan data primer dilakukan melalui survei ke lapangan secara langsung yang disertai dengan wawancara secara terbuka yang dilakukan dengan Pegawai Badan Pengelolaan Lingkungan Hidup Daerah Provinsi Lampung yang sifatnya untuk suatu waktu tertentu melalui penyebaran kuesioner tertulis dengan model kuisioner tertutup dengan tujuan agar Pegawai Badan Pengelolaan Lingkungan Hidup Daerah Provinsi Lampung tidak mempunyai kesempatan untuk menjawab diluar jawaban yang telah disediakan penulis, sehingga memudahkan penulis untuk membahas penelitian.

b. Data Sekunder

Mencatat data-data yang dipublikasikan oleh Badan Pengelolaan Lingkungan Hidup Daerah Provinsi Lampung dalam bentuk aplikasi dilapangan yang sifatnya berkala sperti yang telah disajikan dalam table-tabel pada latar belakang penulisan.

\section{Sampel dan Populasi}

Menurut Sugiyono sampel adalah bagian atau jumlah dan karakteristik yang dimiliki oleh populasi tersebut. Bila 
populasi besar, dan peneliti tidak mungkin mempelajari semua yang ada pada populasi. Apa yang dipelajari dari sampel itu, kesimpulannya akan diberlakukan untuk populasi. Untuk sampel yang diambil dari populasi haru benar-benar representative (Sugiyono, 2011). Untuk mengukur jumlah sampel mengacu kepada pendapat Slovin (Suliyanto 2006 : 100) dengan rumus sebagai berikut :

$$
n=\frac{N}{1+N e^{2}}
$$

Keterangan :

n :Besarnya Sampel

N :Besarnya Populasi

E :Tingkat signifikan atau persentasi kelonggaran ketidaktelitian karena kesalahan pengambilan sampel yang masih dapat ditolerir atau diinginkan.

Berdasarkan rumus diatas maka besaran sampel yang diteliti dengan asumsi persentase ketidaktelitian sebesar $10 \%$ yang dimana $\mathrm{N}$ (besarnya populasi) diperoleh $\mathrm{N}$ $=70$ dari data BPLHD (Lampiran absen pegawai BPLHD) adalah sebagai berikut :

$$
\begin{gathered}
n=\frac{70}{1+70(0,1)^{2}} \\
n=\frac{70}{2,03} \\
n=34,482
\end{gathered}
$$

Jadi, jumlahnya sebesar 34,482 dan kemudian dibulatkan menjadi 34 responden.

\section{Metode Analisis Data}

Analisis kualitatif ini digunakan untuk menganalisis hasil penelitian dan mencari pemecahannya dengan menggunakan teori-teori yang berkaitan dengan tekanan kerja dan kinerja pegawai.
Untuk mengetahui pengaruh variabel $\mathrm{X}$ dan variabel $\mathrm{Y}$ maka menggunakan rumus regresi. Regresi yang digunakan dalam penelitian ini adalah regresi linear sederhana

Rumus regresi menurut Supranto :

$$
Y=a+b x+\sum t
$$

Keterangan :

$\mathrm{a}=$ koefesien $\mathrm{a}$

$\mathrm{b}=$ koefesien $\mathrm{b}$

$\mathrm{X}=$ skor dari variabel $\mathrm{X}$ (Beban Kerja)

$\mathrm{Y}=$ skor dari variabel Y (Kinerja)

$\sum t=$ jumlah seluruh nilai

(Supranto 2001 : 183)

Untuk uji t, Pengaruh variabel $\mathrm{X}$ (beban kerja) terhadap $\mathrm{Y}$ (kinerja) signifikan atau tidak, dapat diketahui dengan melakukan uji $\mathrm{t}$ adapun rumus uji $\mathrm{t}$ (Arikunto, 2002 : 263) adalah sebagai berikut :

$$
t=\frac{\sqrt{\left(r^{2}\right)(\mathrm{n}-2)}}{\sqrt{1-\mathrm{r}}}
$$

Keterangan :

$\mathrm{t}=$ Signifikansi pengaruh variabel $\mathrm{X}$ terhadap variabel $\mathrm{Y}$

$r^{2}=$ Koefesien determinasi

$\mathrm{n}=$ Jumlah responden

Adapun uji t dimaksudkan untuk menguji apakah variabel bebas mempunyai pengaruh signifikan terhadap variabel terikat, dengan rumus hipotesis sebagai berikut :

Bila $t_{\text {hitung }}>t_{\text {tabel }}$ maka variabel bebas mempunyai pengaruh signifikan terhadap variabel terikat.

Bila $t_{\text {hitung }}<t_{\text {tabel }}$ maka variabel bebas mempunyai pengaruh yang tidak signifikan terhadap variabel terikat. 
Rumus F :

$$
\begin{gathered}
\text { F hitung }=\frac{J K R}{J K E} \\
\text { F tabel }=F(\mu, b d r, d b e)
\end{gathered}
$$

Keterangan :

$$
\begin{array}{ll}
\mathrm{JKR} & =\text { Jumlah Kuadrat Regresi } \\
\mathrm{JKE} & =\text { Jumlah Kuadrat Error } \\
\mathrm{dbr} & =\text { Derajat Bebas Regresi } \\
\mathrm{dbe} & =\text { Derajat Bebas Error }
\end{array}
$$

Jika $\mathrm{F}$ hitung $>\mathrm{F}$ tabel maka Ho ditolak Jika $\mathrm{F}$ hitung $<\mathrm{F}$ tabel maka Ho diterima

\section{HASIL DAN PEMBAHASAN}

\section{Analisis Kualitatif}

Dalam pertanyaan ini diambil dari 34 responden, dengan karakteristik antara jenis kelamin, umur, dan tingkat pendidikan yang terdiri dari :

Tabel Jenis Kelamin, Usia, dan Tingkat Pendidikan

\begin{tabular}{|l|l|l|}
\hline No. & Keterangan & Jumlah \\
\hline 1. & Jenis Kelamin & \\
\hline & Laki-laki & 36 \\
\hline & Perempuan & 34 \\
\hline & Jumlah & 70 \\
\hline 2. & Usia & \\
\hline & $21-30$ & 20 \\
\hline & $31-40$ & 10 \\
\hline & $41-50$ & 30 \\
\hline & $51-60$ & 10 \\
\hline & Jumlah & 70 \\
\hline 3. & Tingkat Pendidikan & \\
\hline & SMA & 15 \\
\hline & Diploma & 15 \\
\hline & Sarjana S1 & 25 \\
\hline & Sarjana S2 & 15 \\
\hline & Jumlah & 70 \\
\hline
\end{tabular}

Berdasarkan data responden di atas dapat diketahui yang paling banyak adalah 41-50 tahun dengan jenis kelamin pegawai laki-laki lebih banyak 3 orang dari pegawai perempuan dan menurut latar belakang pendidikan responden dengan tingkat pendidikan responden dengan Sarjana S1.

\section{Analisis Kuantitatif}

Berdasarkan hasil perhitungan dengan menggunakan model statistic regresi linear sederhana melalui program SPSS versi 21 diperoleh persamaan berikut

$$
\begin{gathered}
Y=a+B x \\
Y=25,799+0,635 X
\end{gathered}
$$

Keterangan :

$\mathrm{Y}=$ Kinerja Pegawai

$\mathrm{X}=$ Beban Kerja

$\mathrm{a}=$ Konstanta

$\mathrm{b}=$ Koefesien Regresi

Diperoleh nilai-niai sebagai berikut :

$$
\begin{aligned}
& R=0,652 \\
& R^{2}=0,425
\end{aligned}
$$

Berdasarkan pengaruh variabel bebas (Beban Kerja) terhadap variabel terikat (Kinerja) dapat diketahui berdasarkan nilai koefesien determinasi $\left(\mathrm{R}^{2}\right)$ yaitu sebesar 0,425 atau $42 \%$. Artinya variabel beban kerjaberpengaruh pada kinerja pegawai sebesar $42 \%$ dan sisanya $58 \%$ dipengaruhi oleh faktor lainnya yang tidak diidentifikasi dalam penelitian ini, sedangkan korelasi beban kerja dan kinerja pegawai sangat kuat yaitu sebesar 0,652.

\section{Pengujian Hipotesis}

Pengujian keberartian pengaruh variabel bebas, untuk keberartian pengaruh variabel bebas terhadap variabel terikat digunakan uji-t (student test) dengan tingkat kepercayaan $95 \%$ atau alpha 0,05 dan derajat kebebasan $(\mathrm{dk})=\mathrm{n}-\mathrm{k}-1=34-1-$ $1=32$. Kriteria pengujiannya adalah : 
Ho ditolak dan Ha diterima jika thitung

$>$ t tabel

Ho diterima dan Ha ditolak jika thitung

$<$ t tabel

Hasil pengujian dapat dilihat pada tabel 3.7 berikut ini :

\begin{tabular}{|l|l|l|l|}
\hline $\begin{array}{l}\text { Variabel } \\
\text { Bebas }\end{array}$ & t hitung & $\mathrm{t}$ tabel & Kesimpulan \\
\hline $\begin{array}{l}\text { Beban } \\
\text { Kerja }\end{array}$ & 4,864 & 1,691 & $\begin{array}{l}\text { Ho ditolak } \\
\text { dan } \\
\text { Ha diterima }\end{array}$ \\
\hline
\end{tabular}

Sumber : data diolah, 2016

Berdasarkan tabel diatas, mana pengaruh variabel bebas dapat dijelasan bahwa beban kerja memiliki pengaruh yang signifikan terhadap kinerja pegawai. Hasil pengujian hipotesis menunjukan bahwa tingkat kepercayaan $95 \%$ dan derajat kebebasan sebesar 32, nilai t hitung 4,864 adalah lebih besar dari t tabel 1,691. Hal ini berarti bahwa beban kerja memiliki pengaruh yang signifikan terhadap kinerja pegawai BPLHD Provinsi Lampung.

\section{KESIMPULAN DAN SARAN}

\section{Kesimpulan}

Hasil penelitian menemukan bahwa penyebab terbesar terjadinya beban kerja pada pegawai Badan Pengelolaan Lingkungan Hidup Daerah (BPLHD) Provinsi Lampung adalah adanya target dan tuntutan tugas yang memberatkan pekerjaan pegawai, target yang mengharuskan seluruh tugas harus selesai dalam waktu yang hamir bersamaan serta tuntutan untuk tetap menghasilkan kualitas kerja yang maksimal justru membuat kinerja yang dihasilkan para pegawai cenderung rendah karena tidak memiliki cukup waktu untuk menyelesaikannya. Pengujian hipotesis secara keseluruhan yang diperoleh dari $\mathrm{t}$ hitung $=4,864$ lebih besar dari $\mathrm{t}$ tabel $=$
1,691 pada tingkat kepercayaan 95\%. Artinya variabel bebas (beban kerja) berpengaruh secara signifikan terhadap variabel terikat (kinerja). Berdasarkan perhitungan regresi diperoleh koefesien determinasi $\left(\mathrm{R}^{2}\right)$, yaitu sebesar 0,425 atau $42 \%$. Hal ini berarti besarnya pengaruh beban kerja terhadap kinerja pegawai Badan Pengelolaan Lingkungan Hidup Daerah (BPLHD) Provinsi Lampung sebesar $42 \%$ sementara sisanya sebesar $58 \%$ kinerja pegawai dipengaruhi oleh variabel bebas dari luar penelitian ini.

\section{Saran}

1. Berdasrkan hasil penelitian nomor 4 menemukan bahwa penyebab terbesar terjadinya beban kerja pada pegawai BPLHD Provinsi Lampung adalah adanya target dan tuntutan tugas yang memberatkan pekerjaan pegawai, dikarenakan tidak mungkin lagi bagi perusahaan untuk merubah target maka pihak perusahaan perlu memperjelas harapan-harapan perusahaan kepada pegawai, yakni memberikan informasi secara berkala kepada setiap pegawai terkait apa yang harus dikerjakan dalam mencapai target dan tuntutan tugas yang telah ditetapkan seperti informasi tentang pengidentifikasian pekerjaan riwayat pekerjaan, kewajiban-kewajiban pekerjaan dan pertanggungjawaban, spesifikasi pekerjaan atau informasi mengenai standar-standar pekerjaan oleh atasan yang juga harus mendampingi pegawai dalam pelaksanaannya.

2. Dari hasil analisis kuantitatif dapat dilihat bahwa pegawai kurang merasa mendapat penghargaan atas prestasi kerjaannya, hal ini dapat mengurangi semangat dalam melaksanakan pekerjaan, sehingga atasan perlu memberi perhatian lebih atas prestasi kerja pegawainya nseperti memberikan 
pujian saat pegawai mengerjakan tugas tepat waktu, atau mempertimbangkannya dalam pemberian jabatan, karena dengan prestasi kerja yang baik tentunya pegawai telah terbukti memiliki kualitas kerja yang baik pula.

3. BPLHD Provinsi Lampung perlu melakukan pengkategorian tugas berdasarkan jenis pekerjaan jenis pekerjaan, pengetahuan, dan kemampuan sehingga tugas dapat dikerjakan oleh pegawai yang memiliki kompetensi sesuai dengan jenis pekerjaan dan atasan perlu mengawasi jalannya rutinitas pekerjaan sehingga fungsi dari masing-masing bagian dapat diterapkan dengan baik untuk mengatasi masaah beban kerja.

4. Pimpinan BPLHD perlu memperbaiki kemampuan pegawai dalam menyelesaikan maslah yang baik, terutama ketika pegawai berhadapan dengan maslah pekerjaan dlam situasi menantang, pegawai peru diatuih untuk tetap bertahan dan menyeesaikan pekerjaannya.

\section{DAFTAR PUSTAKA}

Arikunto, Suharsimi. 2012. Prosedur penelitian. Jakarta: Rineka Cipta.

Chester, I Bernard . 2010. The communication perspective (terjemahan). Jakarta: Elek Media Komputindo.

Edward H, Schein. 2012. Manajemen Sumber Daya Manusia Untuk Bisnis Kompetitif. Yogyakarta: Gajahmada University Press.

Griffin dan Ebert. 2011. Manajemen Personalia. Jakarta: Gramedia.
Handoko, T. Hani. 2017. Manajemen Personalia dan Manajemen Sumber Daya Manusia. Yogyakarta: BPFE.

Hicks dan gullet, 2016. Managing Cultural Differences. (terjemahan). Jakarta: Elek Media Komputindo.

Kurnianti, tjahjono, 2013.Manajemen Sumber Daya Manusia. Jakarta: Bumi Aksara.

Nawawi, Hadari. 2017. Manajemen Sumber Daya Manusia Untuk Bisnis Kompetitif. Yogyakarta: Gajahmada University Press.

Nitiatmodjo, 2016. Organisasi. Jakarta: Bumi Aksara.

Poster. 2015. Manajemen Sumber Daya Manusia. Yogyakarta:Gajahmada University Press.

Robbins, Stephen P. 2011. Prilaku Organisasi Jilid I. Alih bahasa oleh Drs. Hadyana Pujuutmaka dan Drs. Benyamin Molan. Jakarta: Penerbit Prenhallindo.

Siagian. 2016.Dasar dasarManajemen. Jakarta:Gramedia.

Sudjana. 2017. Metode Statistika. Bandung: Tarsito. 